\title{
Announcement
}

\section{The XIth International Congress of Virology}

\author{
8th-13th August 1999 \\ Sydney, Australia
}

The Virology Division of the International Union of Microbiological Societies (IUMS) is undertaking the organisation of the XIth International Congress of Virology, which will be held at the Sydney Convention and Exhibition Centre, Darling Harbour, Sydney, Australia, from 8th to 13th August 1999. The programme organisation is headed by the Vice-Chair of the Virology Division, R. W. Compans, and the Chair of the National Organising Committee in Australia, J. S. Mackenzie, assisted by an international advisory committee. The programme will consist of five Plenary Sessions in the mornings and sixty-four Workshops in the afternoons. These are listed in the Provisional Programme outlined below. In addition, several special topic sessions and industry symposia will be held during the late afternoons and early evenings. A special Plenary Session will be held on the final afternoon entitled Poliovirus Eradication. The Plenary Meeting of the International Committee on Taxonomy of Viruses (ICTV) will be held also during the course of the Congress.

Over 128 distinguished virologists from 26 countries have accepted invitations to cochair the Workshops. These co-chairs will select eight submitted papers for oral presentation at each workshop, and the remaining offered papers will be presented as posters.

\section{The Virology Division of the International Union of Microbiological Societies}

CHAIRMAN

B. W. J. Mahy (USA)

J.G. Atabekov (Russia)

D. H. L. Bishop (UK)

SECRETARY-TREASURER

H. Zeichhardt

(Germany)
VICE-CHAIR AND CHAIR OF PROGRAMME COMMITTEE

R. W. Compans (USA)

ADVISORY COUNCIL

R. W. Goldbach (The Netherlands)

M. C. Horzinek (The Netherlands)

VIROLOGY DIVISION EDITOR

C. R. Pringle

(UK)
PAST CHAIR

R. F. Pettersson

(Sweden)

\begin{abstract}
A. Nomoto (Japan)
\end{abstract}
A. Vaheri (Finland)

PRESIDENT, INTERNATIONAL COMMITTEE ON TAXONOMY OF VIRUSES

M. H. V. van Regenmortel (France)

VICE-CHAIR, PROGRAMME COMMITTEE, \& CHAIR, 1999 IUMS CONGRESSES ORGANISING COMMITTEE 


\section{Virology Congress National Organising Committee}

1999 IUMS CONGRESSES STEERING COMMITTEE

J. S. Mackenzie (Chair)

D. J. Groot Obbink

P. J. Coloe

J. I. Pitt,

D. O. White

D. H. Ellis

A. J. Gibbs

A. J. Lee

D. W. Smith

A. J. Della Porta

NATIONAL ADVISORY AND ORGANISING COMMITTEE

R. D. Barry

R. Bishop

R. V. Blanden

G. W. Both

D. B. Boyle
C. J. Burrell

R. J. Coelen

Y. E. Cossart

A. L. Cunningham

J. L. Dale

E. J. Gowans

G. S. Grohmann

I. D. Gust

A. W. Hampson

I. H. Holmes

L. C. Jennings

K. G. Kenrick

P. D. Kirkland

S. A. Locarnini

J. Mills

D. Moss

P. K. Murray

A. J. Robinson

J. M. Sabine

G. Shellam

G. A. Smith
M. J. Studdart

R. H. Symons

G. A. Tannock

P. J. Walker

J. M. Whalley

R. C. Weir

E. G. Westaway

P. J. Wright

P. L. Young

P. R. Young

REGIONAL ADVISORY COMMITTEE

M. P. Alpers, PNG

A. Igarashi, Japan

S. K. Lam, Malaysia

H. W. Lee, Korea

M. L. Ng, Singapore

J. Tam, China (Hong Kong)

$P$. Thongcharoen, Thailand

\section{International Programme Advisory Committee}

P. Ahlquist, USA
R. Ahmed, USA

J. W. Almond, UK

J. G. Atabekov, Russia

D. H. Bamford, Finland

Y. Becker, Israel

K. Berns, USA

N. Bhamarapravati, Thailand

M. Billeter, Switzerland

D. H. L. Bishop, UK

J. F. Bol, Netherlands

D. B. Boyle, Australia

G. Bruening, USA

C. J. Burrell, Australia

N. P. Sunil Chandra, India

J. E. Clements, USA

J. Dale, Australia

G. Darai, Germany

G. K. Darby, UK

J. W. Davies, UK

W. O. Dawson, USA

V. Deubel, France

P. C. Doherty, USA

E. Domingo, Spain

R. M. Elliott, UK

B. Fleckenstein, Germany

H. Garoff, Sweden

M. P. Girard, France

A. J. Gibbs, Australia

R. W. Goldbach, Netherlands

E. J. Gowans, Australia

K.-O. Habermehl, Germany

A.-L. Haenni, France

O. A. Haller, Germany

H. zur Hausen, Germany

F. Heinz, Austria
D. D. Ho, USA

T. Hohn, Switzerland

K. V. Holmes, USA

Y. Hosaka, Japan

M. C. Horzinek, Netherlands

P. M. Howley, USA

A. Igarashi, Japan

A. D. Ingot, Poland

L. Kaariainen, Finland

E. D. Kieff, USA

H.-D. Klenk, Germany

D. Kolakofsky, Switzerland

S. K. Lam, Malaysia

R. A. Lamb, USA

M. P. Landini, Italy

J. W. LeDuc, USA

H. W. Lee, Korea

J. A. Levy, USA

B. Lomniczi, Hungary

R. Luftig, USA

D. K. Lvov, Russia

J. S. Mackenzie, Australia

B. W. J. Mahy, USA

J. Maniloff, USA

J. A. Melero, Spain

J. Mills, Australia

A. C. Minson, UK

L. Montagnier, France

F. A. Murphy, USA

A. A. Nash, UK

S. V. Netesov, Russia

G. Neumann, USA

A. Nomoto, Japan

M. B. A. Oldstone, USA

A. Osterhaus, Netherlands

P. Palese, USA
P. Palukaitis, UK

R. Perez-Bercoff, Italy

R. F. Pettersson, Sweden

S. B. Prusiner, USA

D. V. R. Reddy, India

C. M. Rice, USA

M. Rossmann, USA

P. Roy, UK

H. G. Schatzmayr, Brazil

S. Schlesinger, USA

B. Schoub, South Africa

R. Shope, USA

G. L. Smith, UK

W. Spaan, Netherlands

J. Svoboda, Czech

H. Tao, China

M. Tashiro, Japan

V. ter Meulen, Germany

P. Thongcharoen, Thailand

O. Tomori, Zimbabwe

A. Vaheri, Finland

M. van Regenmortel,

France

A. Varma, India

G. Wadell, Sweden

B. Wahren, Sweden

R. G. Webster, USA

R. A. Weiss, UK

Y.-M. Wen, China

G. W. Wertz, USA

R. J. Whitley, USA

E. Wimmer, USA

M. B. Yosef, Israel

M. Yunde, China

H. Zeichhardt, Germany

G. F. Zhu, China 


\title{
An invitation to virologists
}

\author{
J. S. Mackenzie \\ Chair, National Advisory and Organising Committee
}

International Congresses of Virology have become the premier meetings of virologists from around the world, providing the most effective international forum for presenting new results, and providing opportunities for reviewing progress over a wide spectrum of virological topics and issues. The timing of this Congress is most auspicious, being the last before the end of this century and, indeed, of this millenium. It is barely a century since an "ultraparasite", filterable through bacteria-proof filters, was recognised by Ivanovsky as the cause of tobacco mosaic disease, and the term 'virus' was first used by Beijerinck for the same disease. Thus much of our entire discipline was born, nurtured, and developed to its present stature over the past 100 years. Over this period, virology has been central to many highly significant and fundamental advances in biology, particularly in molecular biology, genetics, immunology and biotechnology. We have also witnessed the first planned extinction of an organism with the eradication of smallpox. It is therefore a time to review the current status of virology, and to focus our thoughts and direct our aspirations towards the challenges and opportunities for virologists in the next century and the new millenium. Thus it is fitting that the XIth International Congress of Virology opens with a Plenary Session on the prospects and directions for 'Virology in the 21 st Century' in which five of our most eminent colleagues provide us with their perspectives of the future, and closes with a Plenary Open Forum on a major achievement which is close to fruition, 'Polio Eradication'.

There has been rapid progress in many areas of virology since the last congress in Jerusalem in 1996, and the scientific programme for this, the XIth International Congress, put together by the Programme Chairman in collaboration with the International Programme Advisory Committee, will highlight many of these new developments. While some of these developments have come as a result of new technologies and advances in molecular and immunological techniques, others have resulted from the emergence of new viruses or the spread of known viruses. Australia has perhaps had more than its fair share of the latter in recent years, with the emergence of equine morbillivirus, Australian bat lyssavirus and Menangle virus, and the spread to Australia of Japanese encephalitis virus. The Programme follows the traditional format of Plenary Lectures in the mornings followed by eight or nine concurrent afternoon Workshops of selected papers submitted from virologists from all over the world. The latter provide an indication of the enormous breadth and strength of our discipline.

On behalf of the National Advisory and Organising Committee, and indeed of all Australian virologists, it gives me great pleasure to invite you to join us in Sydney to participate in the XIth International Congress of Virology. Your hosts for the Congress are the Australian Society for Microbiology Inc. and the Australian Academy of Science. We are honoured that so many distinguished scientists have already agreed to join us and to participate in the Congress. We believe that you will have a scientifically stimulating and exciting meeting and we hope you will enjoy the ambience of one of the world's most beautiful cities, Sydney, host for the year 2000 Olympics. We look forward to the opportunity of welcoming you to Sydney, and to your participation in the XIth International Congress of Virology. 


\title{
Provisional Programme for the XIth International Congress of Virology
}

\author{
Sunday, August 8, 1999
}

Opening ceremony: $19.00-20.00$

Official opening: P. C. Doherty

Opening address: D. A. Henderson

An impending World Cup. Man versus Virus.

Reception: 20.00

\section{Monday, August 9, 1999}

Plenary session 1: 09.00-12.00

Virology in the 21 st century

Chairs: F. Fenner, Australia; M. van Regenmortel, France
R. Dulbecco
To be advised
P. Doherty
Virus-specific $\mathrm{CD} 8+\mathrm{T}$ cell responses in respiratory infections
D. Baltimore Progress towards an HIV vaccine
S. Prusiner
Prion biology and diseases
R. Zinkernagel Immunology taught by viruses
Workshops

First Session 13.30-15.30

W54 Virus entry and membrane fusion

Chairs A. Helenius, Switzerland J. M. White, USA

W08 Filoviruses \& filovirus hemorrhagic fevers

Chairs C. J. Peters, USA

R. Swanepoel, South Africa

W20 Picornaviruses

Chairs J. W. Almond, UK

D. Anderson, Australia

W01 Adenoviruses

Chairs W. Doerfler, Germany

W. C. Russell, UK

W03 Ambisense RNA viruses

Chairs R. W. Goldbach, The Netherlands D. Kolakofsky, Switzerland

Second Session 16.00-18.00

W55 Virus receptors

Chairs R. D. Barry, Australia

A. Nomoto, Japan

W22 Reoviruses

Chairs I. H. Holmes, Australia

P. Roy, UK

W05 Calici- and Astroviruses

Chairs P. Wright, Australia

S. S. Monroe, USA

W07 Cytomegalo- and EB viruses

Chairs D. Moss, Australia

U. Koszinowski, Germany

W10 Geminiviruses

Chairs B. D. Harrison, UK

S. G. Lazarowitz, USA

W42 Virus induced immunosuppression

Chairs D. E. Griffin, USA

V. ter Meulen, Germany

W34 Opportunistic infections

Chairs R. A. Weiss, UK

A. Cunningham, Australia

W28 Arboviral diseases

W31 Emerging viral diseases

Chairs D. K. Lvov, Russia

J. S. Mackenzie, Australia

Chairs B. W. J. Mahy, USA

A. Vaheri, Finland

W60 Bacteriophage replication \& expression

Chairs J. Maniloff, USA

M. Salas, Spain

W04 Bornaviruses

Chairs J. C. de la Torre, USA

H. Ludwig, Germany 


\section{Tuesday, August 10, 1999}

Plenary session 2: $09.00-12.00$

Structure and assembly of viruses

Chairs: R. Compans, USA; J. Skehel, UK (to be confirmed)

M. Rossmann Structural adaptations of viruses required to perform complex biological tasks

D. Stuart To be advised

F. Heinz The flavivirus model for envelope glycoprotein structure.

D. Wiley Structure/function studies of viral entry in influenza, HIV, and Ebola viruses

H. Garoff Virus maturation by budding

Workshops

First Session 13.30-15.30

Second Session 16.00-18.00

W47 RNA virus reverse genetics

W37 Vaccine development

Chairs G. W. Wertz, USA

K.-K. Conzelmann, Germany

Chairs I. D. Gust, Australia

N. Bhamarapravati, Thailand

W45 Negative strand viruses replication and transcription

W11 Hantaviruses

Chairs H. W. Lee, Korea

Chairs P. Palese, USA

C. Schmaljohn, USA

M. A. Billeter, Switzerland

W02 Alpha- and Rubiviruses

Chairs J. H. Strauss, USA

M. D. Lindsay, Australia

W09 Flaviviruses

Chairs E. Westaway, Australia

V. Deubel, France

W14 Herpesviruses

Chairs B. Fleckenstein, Germany

M. Studdart, Australia

W12 Hepatitis B virus

Chairs Y-M. Wen, China

C. J. Burrell, Australia

W15 Luteoviruses

Chairs M. Gibbs, Australia

D. V. R. Reddy, India

W56 Plant virus replication \& recombination

Chairs J. F. Bol, The Netherlands

A. E. Simon, USA

W41 Viral vectors and gene therapy

W55 Virus-host protein interactions

Chairs I. Verma, USA

G. Both, Australia

Chairs R. M. Krug, USA

J. Ortin, Spain

W48 Structure \& assembly: enveloped viruses

Chairs E. Hunter, USA

H. Garoff, Sweden

W49 Structure \& assembly: non-enveloped viruses

Chairs D. Stuart, UK

D. H. Bamford, Finland

W62 Insect virus-cell interactions

W60 Lysogeny, lysogenic conversion \& phage-host interactions

Chairs M. D. Summers, USA

L. E Volkman, USA

Chairs M. Smith, UK

L. R. Denes, USA

Wednesday, August 11, 1999

Plenary session 3: 09.00-12.00

Molecular biology/disease control

Chairs: J. Almond, UK; R. Pettersson, Sweden 
J. Carrington

G. Wertz

R. Weiss

I Verma

J. Dale
Genetics of virus-host interactions in plants

Re-engineering the genomes of non-segmented negative strand RNA viruses

To be advised

To be advised

Transgenic resistance to viruses of tropical plants: a complex challenge

Workshops

First Session 13.30-15.30

Second Session $16.00-18.00$

W29 Cellular immunity to viral infections

Chairs R. Ahmed, USA

R. V. Blanden, Australia

W33 HIV pathogenesis

Chairs E. A. Berger, USA

J. Mills, Australia

W18 Paramyxoviruses

Chairs R. A Lamb, USA

M. Tashiro, Japan

W16 Orthomyxoviruses

Chairs R. G. Webster, USA

A. W. Hampson, Australia

W13 Hepatitis C virus

Chairs E. Gowans, Australia

T. Miyamura, Japan

W06 Corona- and Arteriviruses

Chairs K. V. Holmes, USA

P. Rottier, The Netherlands

W17 Papillomaviruses

Chairs I. Frazer, Australia

L. Gissmann, Germany

W19 Parvoviruses

Chairs K. I. Berns, USA

Y. Cossart, Australia

W57 Resistance mechanisms to plant viruses

Chairs R. N. Beachy, USA

D. C. Baulcombe, UK

W58 Virus movements in plants

Chairs J. G. Atabekov, Russia

S. A. Lommel, USA

W42 Host resistance to viral infection

W43 Viruses and apoptosis

Chairs O. A. Haller, Germany

G. R. Shellam, Australia

Chairs J. M. Hardwick, USA

D. Vaux, Australia

W47 Virus evolution and diversity

W23 Retroviruses

Chairs E. Domingo, Spain

A. J. Gibbs, Australia

Chairs S. Wain-Hobson, France

M. Girard, France

W38 Viral diseases in developing countries: clinical aspects and control

Chairs A. Varma, India

P. Thongcharoen, Thailand

W39 Viral diseases in developing countries: epidemiology \& surveillance

Chairs J. Tam, China (Hong Kong)

O. Tomori, Zimbabwe

W30 DNA vaccines

Chairs H. Robinson, USA

To be advised

Special symposium: Veterinary viruses

Chairs M. C. Horzinek, The Netherlands To be advised

\section{Thursday, August 12, 1999}

Plenary session 4: 09.00-12.00

Immunobiology and pathogenesis of viral infections

Chairs: Y. Becker, Israel; H. Zeichhardt, Germany
H. Ploegh
To be advised
R. Ahmed
$\mathrm{T}$ cell immunity during acute and chronic viral infection
M. Oldstone
Viral diseases in the 21 st century
M. Estes
To be advised
L. Gissmann
Development of vaccines against HPV-related cancer 
Workshops

First Session 13.30-15.30

W35 Persistent infections

Chairs A. T. Haase, USA

M. B. A. Oldstone, USA

W51 Viral glycoproteins

Chairs H-D. Klenk, Germany

K. Nakamura, Japan

W46 Positive strand RNA viruses: replication and transcription

Chairs P. Ahlquist, USA

E. Wimmer, USA

W21 Poxviruses

Chairs S. Shchelkunov, Russia

B. Moss, USA

W26 Viroids \& satellite viruses (animal/plant)

Chairs R. Symons, Australia

J. M. Taylor, USA

W36 Prions: biology and disease

Chairs C. Bostock, UK

B. W. Chesebro, USA

W65 Viral diagnostics

Chairs S. K. Lam, Malaysia

L. C. Jennings, New Zealand

W64 Virus taxonomy

Chairs F. A. Murphy, USA

D. H. L. Bishop, UK
Second Session 16.00-18.00

W40 Viral strategies \& immune recognition

Chairs L. Gooding, USA

H. Ploegh, USA

W24 Rhabdoviruses

Chairs A. Flamand, France

P. Walker, Australia

W53 Viral proteases

Chairs C. M. Rice, USA

A. Gorbalenya, USA

W50 Transcription of DNA viruses

Chairs C. M. Preston, UK

A. Minson, UK

Rotaviruses

Chairs M. Estes, USA

R. Bishop, Australia

W44 Viruses and cancer

Chairs M. Bendinelli, Italy

R. F. Pettersson, Sweden

W63 Viral bioinformatics

Chairs M. C. Horzinek, The Netherlands

E. P. Rybicki, South Africa

W61 Viruses of fungi and protozoa

Chairs D. L. Nuss, USA

K. W. Buck, UK

W27 Antiviral agents

Chairs S. Locarnini, Australia

To be advised

Friday, August 13, 1999

Plenary session 5: 09.00-12.00

Viral emergence and evolution

Chairs: J. S. Mackenzie, Australia; B. W. J. Mahy, USA
E. Domingo
Molecular basis for fitness variations in RNA viruses
C. Bostock
Strains of agent and host genes in the transmissible spongiform encephalopathies
S. Wain-Hobson
Misunderstanding RNA viral evolution - some thoughts from HIV
R. Webster
Influenza: lessons from H5N1 in Hong Kong
A. Gibbs
Phylogenetic phantasmagoria 
Open forum: $13.30-15.30$

Polio eradication

Chairs: W. Dowdle, USA; E. Wimmer, USA

Current status and timetable for global eradication.

Presenter R. Sanders

Moderator J. Almond

How will we know that poliovirus has been eradicated?

Presenter O. Kew

Moderator F. Fenner

What are the options for stopping immunisation and how will we decide?

Presenter M. Pallansch

Moderator V. Agol

Could poliomyelitis come back?

Presenter P. Minor

Moderator A. Nomoto

How will we know that laboratory containment of poliovirus has been achieved?

Presenter A. van Loon

Moderator K. Habermehl

Closing ceremony

15.30-16.00

In the week following the Congress of Virology, the IXth International Congress of Mycology and the IXth International Congress of Bacteriology and Applied Microbiology will be held at the same venue. The Congress organisers can be contacted at the IUMS Secretariat, 66 King Street, Sydney, New South Wales 2000, Australia; tel: +61-2-92480812; fax: +61-2-9262-3135; e-mail: tourhosts@tourhosts.com.au. Up-dated information on the Virology Congress programme and arrangements can be obtained also from the Virology Division Web site at http://www.iums.rdg.ac.uk/virology/home/html.ssi.

\section{A special IUMS symposium on 'bio-terrorism'}

A special IUMS Symposium on 'bio-terrorism' is planned for the afternoon of Saturday, 14th August, 1999. This Symposium will be an Inter-Divisional Symposium, jointly sponsored by the Divisions of Virology, Bacteriology and Applied Microbiology, and Mycology. It will be chaired by Professor D. A. Henderson, and will take place in the main auditorium of the Sydney Convention Centre. Speakers for the Symposium have not yet been confirmed, but will be circulated widely once available. Registration for the Symposium will be extra, and has been set at $\$ 35.00$ for full registrants of the International Congress of Virology, International Congress of Bacteriology and Applied Microbiology, or the International Congress of Mycology. 


\section{Addendum}

Registration and Abstract Submission Forms for all three IUMS Congresses are now available on the internet. Registration and submission of abstracts can be carried out electronically. The Web-site for the IUMS Congresses also contains general information about the congresses, programmes for plenary sessions, workshops and satellite meetings, and post-congress tour itineraries. The web-site address is the following:

www.tourhosts.com.au/iums

Verleger: Springer-Verlag KG, Sachsenplatz 4-6, A-1201 Wien. - Herausgeber: Dr. F. A. Murphy, School of Veterinary Medicine, University of California Davis, Davis, CA 95616, U.S.A. - Redaktion: Sachsenplatz 4-6, A-1201 Wien. - Satz und Umbruch: Thomson Press (India) Ltd., New Delhi. - Offsetdruck: Adolf Holzhausens Nachfolger, Kandlgasse 19-21, A-1070 Wien. - Umschlagentwurf: Ecke Bonk. - Herstellungsort: Wien. - Printed in Austria. 